\title{
MILLEPORA CFRULEA.
}

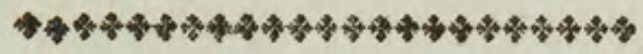 \\ CHARACTER GENERICUS.}

Animal Hydra.

Corallium poris turbinatis teretibus.

Lin. Syst. Nat. p. 1282.

CHARACTER SPECIFICUS, EंC.

MILLEPORA polymorpha subcompressa cærulea, poris inæqualibus.

MILLEPORA plana scabra, laminis crassis varie tortuosis subdivisa, apicibus sæpe lobatis porisque substellatis cylindricis utrinque instructis.

Soland. et Ell. zooph. p. 142. t. 12. et 56. CORALLOIDES philippensis cærulea.

$$
\text { Pet. gaz. t. 10. f. } 12 .
$$

In maribus Indicis præcipue conspicitur formosum hoc curalium, magnitudine vera in tabula expressum. 



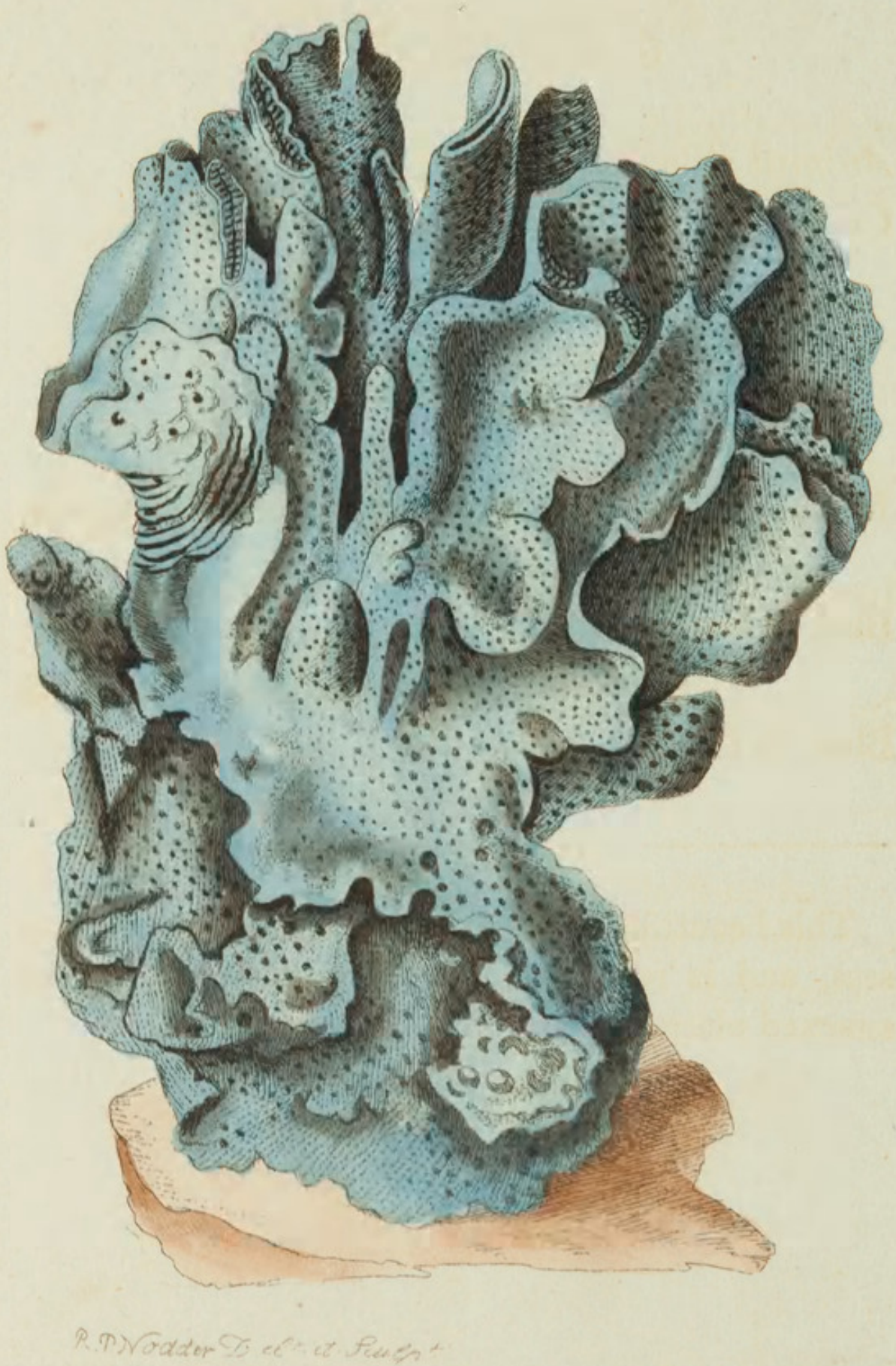




\section{BLUE MILLEPORE.}

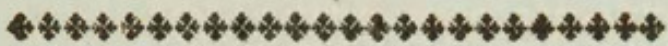

\section{GENERIC CHARACTER.}

Animal allied to a Polype.

Coral with very numerous cylindric pores.

\section{SPECIFIC CHARACTER, EZe.}

Polymorphous, subcompressed, blue Millepore, with unequal pores.

Blue MILLEPORE.

Soland. et Ellis zooph. t. 12. et 56. Blue INDIAN CORAL.

This beautiful Coral is chiefly seen in the Indian seas, and is represented in its natural size on the annexed plate. 


\section{$2 \mathrm{BHL}$ Biodiversity Heritage Library}

Shaw, George. 1805. "Blue Millepore, Millepora cærulea [PI. 666]." The Naturalist's Miscellany 16(CLXXXIX), https://doi.org/10.5962/p.311106.

View This Item Online: https://www.biodiversitylibrary.org/item/281942

DOI: https://doi.org/10.5962/p.311106

Permalink: https://www.biodiversitylibrary.org/partpdf/311106

\section{Holding Institution}

Museums Victoria

\section{Sponsored by}

Atlas of Living Australia

\section{Copyright \& Reuse}

Copyright Status: Public domain. The BHL considers that this work is no longer under copyright protection.

This document was created from content at the Biodiversity Heritage Library, the world's largest open access digital library for biodiversity literature and archives. Visit BHL at https://www.biodiversitylibrary.org. 